\title{
OCHRONA STOSUNKU ZATRUDNIENIA DZIAŁACZY ZWIAZZKOWYCH PO NOWELIZACJI USTAWY ZWIĄZKOWEJ Z DNIA 5 LIPCA 2018 ROKU W ŚWIETLE STANDARDÓW MIĘDZYNARODOWEGO PRAWA PRACY
}

\begin{abstract}
The protection of employment relationship of trade union activists in the view of the amendment of $\mathbf{5}$ July $\mathbf{2 0 1 8}$ to the Trade Unions Act and international labour law standards

The subject of the study is the protection of employment relations of trade unionists after the amendment of 5 July 2018 to the Trade Unions Act. The amendment has introduced many significant changes. Especially, protection were granted to large groups of trade unionists who are not employees, in particular self-employed workers and those providing work under civil law. The article analyses the objective and subjective scope of protection, claims for breach of protection and procedural aspect of protection. The author focuses her attention on assessing current legal protection of employees' representatives in the light of international labour law standards.
\end{abstract}

Keywords: trade unionists, protection of employment relations, civil law employment, self-employment, claims

Słowa kluczowe: działacze związkowi, ochrona stosunku zatrudnienia, zatrudnienie cywilnoprawne, samozatrudnienie, roszczenia

ASJC: 3308, JEL: K31, K33

\section{Uwagi wstępne}

Prawidłowe wypełnianie funkcji przedstawiciela pracowników wymaga zagwarantowania ochrony stosunku zatrudnienia. Przedstawiciele pracowników, reprezentując i broniąc praw i interesów pracowniczych, stawiają interesy pracowników przed interesami pracodawcy. W ten sposób narażają się na zachowania odwetowe ze strony pracodawcy. Stąd też właściwe wypełnianie funkcji przedstawiciela pracowników wymaga zapewnienia ochrony przed represjami ze strony pracodawców (Gernigon, Odero, Guido 1998, s. 464). Rozwiązanie takie ma więc wymiar ponadindywidualny, jego 
istotą jest bowiem stworzenie możliwości reprezentacji praw i interesów pracowników. Ochrona przedstawicieli pracowników, będąca przedmiotem licznych wytycznych organów kontrolnych Międzynarodowej Organizacji Prawy (dalej: MOP), uznawana jest za niezbędną do korzystania z praw zbiorowych (Freedom of Association 2006, $\$ \$ 773$, 769, 810-811; Gernigon, Odero, Guido 1998, s. 461-462, 464).

Nowelizacja z 2018 roku (ustawa z dnia 5 lipca 2018 roku o zmianie ustawy o związkach zawodowych oraz niektórych innych ustaw, Dz.U. 2018, poz. 1608 ze zm., dalej: nowelizacja z 2018 roku) ustawy z dnia 23 maja 1991 roku o związkach zawodowych (Dz.U. 2019, poz. 263 tekst jedn., dalej: ustawa o związkach zawodowych, u.z.z.) wprowadziła wiele istotnych zmian w sferze ochrony działaczy związkowych. Poniższe rozważania nie mają jednak na celu omówienia wszystkich nowych rozwiązań, lecz ocenę stanu prawnego po nowelizacji w świetle prawa międzynarodowego. Nowe unormowania z zakresu ochrony działaczy związkowych były już zresztą przedmiotem opracowań w doktrynie, do których w tym miejscu należy jedynie odesłać (Baran 2018a; Baran 2018b, s. 21-26; Dral 2018, s. 243-269; Baran 2019, s. 214-233; Grzebyk 2019, s. 223-237; Pisarczyk 2019, s. 299-320).

\section{Zakres podmiotowy i przedmiotowy ochrony trwałości zatrudnienia}

W związku z rozszerzeniem zakresu podmiotowego prawa zrzeszania się w związkach zawodowych na nowe grupy podmiotów, wprowadzono mechanizmy ochrony trwałości stosunku prawnego wobec działaczy związkowych niebędących pracownikami w rozumieniu ustawy z dnia 26 czerwca 1974 roku - Kodeks pracy (Dz.U. 2019, poz. 1040 tekst jedn. ze zm., dalej: Kodeksu pracy, k.p.). Zgodnie ze zmienionym art. 32 u.z.z. ochroną trwałości stosunku prawnego zostali objęci:

1) wskazani uchwałą członkowie zarządu zakładowej organizacji związkowej (ust. 1),

2) wskazane uchwałą zarządu osoby wykonujące pracę zarobkową będące członkami zakładowej organizacji związkowej, upoważnione do reprezentowania tej organizacji wobec pracodawcy albo organu lub osoby dokonującej za pracodawce czynności w sprawach z zakresu prawa pracy (ust. 1),

3) wskazane uchwałą komitetu założycielskiego trzy osoby wykonujące pracę zarobkową (ust. 7),

4) osoby wykonujące pracę zarobkową pełniące $\mathrm{z}$ wyboru funkcję związkową poza zakładową organizacją związkową, korzystające u pracodawcy z urlopu bezpłatnego lub ze zwolnienia z obowiązku świadczenia pracy (ust. 9)1.

Definicję osoby wykonującej pracę zarobkową zawiera art. 11 pkt 1 u.z.z.. W pojęciu tym mieszczą się z jednej strony pracownicy, z drugiej inne osoby świadczące pracę za wynagrodzeniem na innej podstawie niż stosunek pracy, jeżeli nie zatrudniają do

${ }^{1} \mathrm{Z}$ urlopu bezpłatnego mogą korzystać tylko pracownicy, a ze zwolnienia z obowiązku świadczenia pracy wszystkie kategorie osób wykonujących pracę zarobkową. 
tego rodzaju pracy innych osób, niezależnie od podstawy zatrudnienia, i jeżeli mają takie prawa i interesy związane $\mathrm{z}$ wykonywaniem pracy, które mogą być reprezentowane i bronione przez związek zawodowy.

Zarówno na gruncie dotychczasowego, jak i nowego brzmienia art. 32 u.z.z. szczególna ochrona zatrudnienia działaczy związkowych jest realizowana za pomocą warunku uzyskania zgody organu związkowego. Pracodawca nie może bez zgody właściwego organu związkowego wypowiedzieć oraz rozwiązać stosunku prawnego ani też zmienić jednostronnie warunków pracy lub wynagrodzenia na niekorzyść osoby wykonującej pracę zarobkową z wyjątkiem przypadku ogłoszenia upadłości lub likwidacji pracodawcy, a także jeżeli dopuszczają to przepisy odrębne (art. 32 ust. 1 u.z.z.) $)^{2}$. Zakres przedmiotowy ochrony działaczy związkowych niebędących pracownikami jest identyczny jak w przypadku pracowników. Gwarancje ochronne określone w art. 32 u.z.z. odnoszą się zarówno do wypowiedzenia, rozwiązania, jak i do jednostronnej zmiany stosunku prawnego na niekorzyść działacza związkowego. W praktyce jednostronna zmiana umowy cywilnoprawnej będącej podstawą zatrudnienia działacza związkowego jest jednak niezwykle rzadka i może nastąpić, jeśli strony dopuściły taką możliwość w zawartej umowie.

Zgodnie z uzasadnieniem do projektu zmieniającego ustawę o związkach zawodowych znaczące rozszerzenie zakresu podmiotowego ochrony w stosunku do poprzednio obowiązujących unormowań podyktowane było potrzebą dostosowania prawa polskiego do prawa międzynarodowego (uzasadnienie rządowego projektu ustawy o zmianie ustawy o związkach zawodowych oraz niektórych innych ustaw, druk sejmowy nr 1933, Sejm VIII kadencji, s. 42). W tym zakresie przytoczono art. 1 Konwencji nr 135 dotyczącej ochrony przedstawicieli pracowników w przedsiębiorstwach i przyznania im ułatwień, przyjętej w Genewie dnia 2 czerwca 1971 roku (Dz.U. 1977, nr 39, poz. 178, dalej: Konwencja nr 135 MOP), zgodnie z którym działacze związkowi jako przedstawiciele pracowników w przedsiębiorstwie powinni korzystać ze skutecznej ochrony przeciwko wszelkim krzywdzącym aktom, włącznie ze zwolnieniem, podjętym ze względu na ich charakter lub działalność jako przedstawicieli pracowników, ich członkostwo związkowe lub też uczestnictwo w działalności związkowej, jeżeli działają zgodnie z obowiązującymi przepisami ustawodawstwa, układami zbiorowymi lub innymi wspólnie uzgodnionymi porozumieniami ${ }^{3}$. Należy przy tym dodać, że zgodnie z wytycznymi organów kontrolnych MOP ochrona przed dyskryminacją antyzwiązkową nie ogranicza się do osób zatrudnionych na podstawie stosunku pracy, lecz odnosi się do wszystkich zatrudnionych bez względu na podstawę prawną świadczenia pracy. MOP stoi bowiem na stanowisku, że wszystkie osoby pracujące w szerokim tego słowa znaczeniu powinny mieć

${ }^{2}$ Zgodę na wypowiedzenie, rozwiązanie lub zmianę stosunku prawnego wyraża zarząd zakładowej organizacji związkowej (art. 32 ust. 1 u.z.z.), komitet założycielski zakładowej organizacji związkowej (art. 32 ust. 7 u.z.z.) lub odpowiednio właściwy statutowo organ organizacji związkowej, w której osoba wykonująca pracę zarobkową pełni albo pełniła funkcję związkową (art. 32 ust. 9 u.z.z.).

${ }^{3}$ Podobnie stanowi ust. 5 Zalecenia z 23 czerwca 1971 roku nr 143 MOP dotyczącego ochrony przedstawicieli pracowników w przedsiębiorstwach i przyznania im ułatwień (dalej: Zalecenie nr 143 MOP). 
prawo do organizowania się, ochrony swoich praw do organizowania i mieć prawo do wspólnego głosu. Stąd też MOP wywodzi, że także ochrona przedstawicieli pracowników powinna dotyczyć wszystkich osób pracujących ${ }^{4}$. Konwencja nr 135 MOP nie precyzuje środków ochronnych, lecz stanowi jedynie, że ochrona przed wszelkimi aktami krzywdzącymi powinna być „skuteczna”. Wykaz tych środków zawiera zaś Zalecenie nr 143 MOP (szerzej: Kurzynoga 2019, s. 1091-1101).

O ile z prawa międzynarodowego wynika konieczność zapewnienia skutecznej ochrony przedstawicielom pracowników przeciwko wszelkim krzywdzącym aktom, włącznie ze zwolnieniem, o tyle ustanowione w prawie polskim środki ochrony budzą wątpliwości. Przewidziane w art. 32 u.z.z. unormowanie było przedmiotem krytyki już przed nowelizacją z 2018 roku, która objęła wskazaną regulacją także osoby świadczące pracę na innej podstawie niż umowa o pracę. Uzyskanie zgody przedstawicielstwa pracowniczego na rozwiązanie stosunku prawnego $\mathrm{z}$ działaczem związkowym budzi zastrzeżenia i wykracza poza to, co jest niezbędne z prawa międzynarodowego. Wśród środków ochrony Zalecenie nr $143 \mathrm{MOP}$ wymienia, co prawda, między innymi obowiązek uzyskania zgody na zwolnienie z pracy przedstawiciela pracowników (ust. 6 pkt a), jednakże zalecenie wskazuje na niezależny organ, a nie jak w przypadku polskich regulacji przedstawicielstwo pracownicze. Ponadto warunek uzyskania zgody na rozwiązanie stosunku prawnego osób wykonujących pracę zarobkową niebędących pracownikami wywiera wpływ na prawa i obowiązki stron umów cywilnoprawnych. Ponieważ umowy o świadczenie usług na warunkach zlecenia, umowy o dzieło czy innych umów o zatrudnienie cywilnoprawne stanowią przedmiot regulacji ustawy z dnia 23 kwietnia 1964 roku - Kodeks cywilny (Dz.U. 2019, poz. 1145 ze zm.), to także unormowania tego kodeksu powinny decydować o sposobie, w jaki te stosunki prawne zostają ukształtowane. Przyznanie wskazanej ochrony osobom zatrudnionym na podstawie umów cywilnoprawnych spowodowało, że stosunek cywilnoprawny pomimo swej istoty podlega ochronie prawnej na podstawie norm prawa pracy. Podstawowym narzędziem ochrony przedstawicieli pracowników niebędących pracownikami powinny być przepisy dyskryminacyjne oraz wysokie odszkodowania (Arkadiusz Sobczyk prezentuje taki pogląd w odniesieniu do wszystkich działaczy związkowych; 2017, s. 178). Środki takie byłyby wystarczające z punktu widzenia prawa międzynarodowego, a jednocześnie nie ingerowałyby nadmiernie w stosunki cywilnoprawne.

${ }^{4}$ W odpowiedzi na skargę złożoną w 2011 roku przez Komisję Krajową NSZZ „Solidarność” do Komitetu Wolności Związkowej MOP dotyczącą naruszeń wolności związkowych Komitet zwrócił się do rządu polskiego o zapewnienie, aby wszystkie osoby zatrudnione i ich przedstawiciele mieli zagwarantowaną odpowiednią ochronę przed wszelkimi aktami dyskryminacji dążącymi do naruszenia wolności związkowej w dziedzinie pracy, niezależnie od tego, czy osoby te mieszczą się w definicji pracowników przyjętej w Kodeksie pracy, czy też nie (Podgórska-Rakiel 2013, s. 72). Stanowisko to potwierdziła Misja Międzynarodowej Organizacji Pracy, która miała miejsce w Polsce w dniach 14-16 maja 2014 roku, w ramach tzw. pomocy technicznej oferowanej przez MOP. Celem Misji MOP w Polsce była analiza polskiego ustawodawstwa w zakresie wolności związkowych, w szczególności w kontekście osób świadczących pracę na podstawie umów cywilnoprawnych i osób samozatrudnionych oraz przedstawienie standardów i zaleceń zgodnych z poglądami MOP (Podgórska-Rakiel 2014, s. 510-511). 
Mankamentem nowelizacji z 2018 roku jest także nieograniczenie ochrony do przypadków związanych z działalnością związkową. Utrzymana została ochrona działacza związkowego nawet w wypadkach ciężkiego naruszenia przez niego podstawowych obowiązków pracowniczych. Naruszenie przez pracodawcę art. 32 u.z.z., a więc zwolnienie chronionego działacza związkowego bez zgody właściwego organu związkowego, stanowi naruszenie przepisów o rozwiązywaniu umowy o pracę, co uzasadnia roszczenia pracownika o przywrócenie do pracy lub o odszkodowanie (art. $45 \$ 1$, art. $50 \$ 5$, art. $56 \$ 1$ k.p.). W myśl art. $45 \$ 2$ k.p. sąd pracy może nie uwzględnić żądania pracownika uznania wypowiedzenia za bezskuteczne lub przywrócenia do pracy, jeżeli ustali, że uwzględnienie takiego żądania jest niemożliwe lub niecelowe. W takim wypadku sąd pracy orzeka o odszkodowaniu. Jednakże z treści art. $45 \$ 3$ i art. $56 \$ 2$ k.p. wynika zakaz orzekania o odszkodowaniu w miejsce przywrócenia do pracy w przypadku pracownika objętego szczególną ochroną przed wypowiedzeniem i rozwiązaniem stosunku pracy, chyba że uwzględnienie żądania przywrócenia do pracy jest niemożliwe ze względu na upadłość lub likwidację pracodawcy. Skutkiem rozwiązania przez pracodawcę stosunku pracy z chronionym działaczem związkowym bez zgody właściwego organu związkowego jest co do zasady uwzględnienie żądania pracownika przywrócenia do pracy i zasądzenie wynagrodzenia za cały czas pozostawania bez pracy (art. 47 i $57 \$ 2$ k.p.). Co prawda, Sąd Najwyższy na podstawie art. 8 k.p. dopuszcza możliwość uznania roszczenia o przywrócenie do pracy zgłoszone przez pracownika objętego ochroną przed rozwiązaniem stosunku pracy z art. 32 u.z.z. za bezzasadne - gdy okaże się nieuzasadnione ze względu na jego sprzeczność ze społeczno-gospodarczym przeznaczeniem prawa lub zasadami współżycia społecznego - jednakże możliwość ta ma charakter nadzwyczajny.

Tak daleko idąca ochrona związkowa nie znajduje uzasadnienia w prawie międzynarodowym. Przytoczony wcześniej art. 1 Konwencji nr 135 MOP oraz ust. 5 uzupełniającego tę konwencję Zalecenia nr 143 MOP stanowią, że przedstawiciele pracowników powinni korzystać ze skutecznej ochrony przeciwko wszelkim krzywdzącym aktom, włącznie ze zwolnieniem, podjętym ze względu na ich charakter lub działalność jako przedstawicieli pracowników, ich członkostwo związkowe lub też uczestnictwo w działalności związkowej, jeżeli działają zgodnie z obowiązującymi przepisami ustawodawstwa, układami zbiorowymi lub innymi wspólnie uzgodnionymi porozumieniami. Ponadto Konwencja (nr 87) dotycząca wolności związkowej i ochrony praw związkowych, przyjęta w San Francisco dnia 9 lipca 1948 roku (Dz.U. 1958, nr 29, poz. 125) w art. 8 ust. 1 stanowi, że w wykonywaniu przyznanych nią uprawnień pracownicy, pracodawcy i ich odnośne organizacje powinni, podobnie jak inne osoby lub zorganizowane zbiorowości, przestrzegać obowiązujących w kraju przepisów prawnych. Z prawa międzynarodowego jednoznacznie wynika, że szczególna ochrona przedstawicieli pracowników ma jedynie zapobiec aktom krzywdzącym ze względu na pełnienie funkcji przedstawiciela pracowników. Zgodnie ze stanowiskiem Komitetu Wolności Związkowej MOP zasada, że działacz związkowy nie powinien ponosić ujemnych konsekwencji w związku z działalnością związku zawodowego, nie oznacza, iż pełnienie funkcji związkowej zapewnia 
mu immunitet przed zwolnieniem, niezależnie od okoliczności (Hodges-Aeberhard, Odero de Dios 1987, s. 557; Freedom of Association 2006, § 801). Jak wskazał Komitet, o ile jednym ze sposobów zapewniających ochronę osób pełniących funkcję związkową jest przepis zakazujący ich zwolnienia - czy to w trakcie kadencji, czy przez pewien okres po jej upływie - o tyle nie dotyczy on przypadków ciężkiego naruszenia obowiązków (serious misconduct) (Hodges-Aeberhard, Odero de Dios 1987, s. 557; Freedom of Association 2006, $\$ 804$; Servais 2017, s. 114). Za przyczyny uzasadniające rozwiązanie stosunku pracy z działaczem związkowym Komitet Wolności Związkowej uznał między innymi prowadzenie działań związkowych w godzinach pracy przy wykorzystaniu do tego personelu pracodawcy bez jego zgody (Freedom of Association 2006, § 809), nieuzgodnioną z pracodawcą nieobecność $\mathrm{w}$ pracy wynikającą $\mathrm{z}$ uczestnictwa $\mathrm{w}$ szkoleniu (Freedom of Association 2006, $\$ 805$ ) czy też podjęcie nielegalnego strajku (Freedom of Association $2006 \$ 850)^{5}$. Tak więc $z$ uwagi na ochronę interesu pracodawcy oraz poczucie sprawiedliwości społecznej nasuwa się postulat de lege ferenda, aby ochronę działaczy związkowych ograniczyć do wypadków, w których występuje związek między działaniami pracodawcy a funkcją pełnioną przez osobę zatrudnioną.

\section{Roszczenia z tytułu naruszenia szczególnej ochrony trwałości zatrudnienia działaczy związkowych}

Omawiana nowelizacja nie wprowadziła żadnych zmian w sferze roszczeń działaczy związkowych, których łączy z pracodawcą stosunek pracy. Naruszenie przez pracodawcę art. 32 ust. 1 pkt 1 u.z.z., a więc zwolnienie chronionego działacza związkowego lub też zmiana na niekorzyść pracownika bez zgody organu związkowego, jest skuteczne, aczkolwiek stanowi naruszenie przepisów, co uzasadnia roszczenia pracownika z Kodeksu pracy. W zależności od swojej sytuacji oraz decyzji działacz związkowy może wystąpić do sądu o uznanie wypowiedzenia za bezskuteczne, przywrócenie do pracy, odszkodowanie albo przywrócenie poprzednich warunków pracy.

Jeśli zaś chodzi o działaczy związkowych niebędących pracownikami brak jest możliwości stwierdzenia nieważności czynności prawnej czy też przywrócenia do pracy. W trakcie Misji MOP w Polsce w 2014 roku przedstawiciele MOP zaznaczyli, że w wypadku samozatrudnionych lub pracujących na podstawie umów cywilnoprawnych nie można zakładać obowiązku kontynuacji lub rozszerzenia umów tymczasowych z powodu pełnienia (z powołania lub wyboru) funkcji w związku zawodowym. Jedynym

${ }^{5}$ W przypadku strajku kontrolerów ruchu lotniczego, który stanowił zagrożenie dla bezpieczeństwa publicznego, Komitet uznał, że nie może występować z wnioskiem do rządu o zgodę na powrót do pracy osób zwolnionych, czego żądała strona składająca skargę. Za istotne w sprawie Komitet uznał, że przewidziany w prawie krajowym zakaz strajku kontrolerów ruchu lotniczego pozostaje w zgodzie $\mathrm{z}$ prawem międzynarodowym. Wśród usług zasadniczych, w których dopuszczalne są ograniczenia prawa do strajku, a nawet całkowity zakaz tego prawa, organy kontrolne MOP wymieniają między innymi kontrolę ruchu lotniczego. 
oczekiwaniem Misji w zakresie ochrony przed dyskryminacją związkową wspomnianych kategorii osób pracujących było ustanowienie w prawie krajowym środków prawnych mających na celu zapobieżenie możliwości rozwiązania lub niepodpisania umowy z powodu sprawowania funkcji bądź działalności w związku zawodowym6.

W celu zabezpieczenia interesów działaczy związkowych niebędących pracownikami na wypadek naruszenia przez pracodawcę normy z art. 32 ust. 1 u.z.z. w ustawie o związkach zawodowych przewidziano instytucję rekompensaty pieniężnej, która przysługuje niezależnie od wysokości poniesionej szkody. Zgodnie z dodanym ust. 13 w art. 32 u.z.z. wysokość rekompensaty jest równa sześciomiesięcznemu wynagrodzeniu przysługującemu tej osobie w ostatnim okresie zatrudnienia, a w przypadku gdy wynagrodzenie tej osoby nie jest wypłacane w okresach miesięcznych - równa sześciokrotności przeciętnego wynagrodzenia miesięcznego w gospodarce narodowej w roku poprzednim, ogłaszanego przez Prezesa Głównego Urzędu Statystycznego w Dzienniku Urzędowym Rzeczypospolitej Polskiej „Monitor Polski”, na podstawie art. 5 ust. 7 ustawy z dnia 4 marca 1994 roku o zakładowym funduszu świadczeń socjalnych (Dz.U. 2019, poz. 1352 tekst jedn. ze zm.). Możliwość uzyskania rekompensaty w wysokości sześciokrotności miesięcznego wynagrodzenia nie wyczerpuje jednak wszystkich roszczeń, których może dochodzić działacz związkowy niebędący pracownikiem. Artykuł 32 ust. 13 u.z.z. stanowi, że osoba taka może również dochodzić odszkodowania lub zadośćuczynienia przenoszącego wysokość rekompensaty ${ }^{7}$. Rozwiązanie takie należy ocenić pozytywnie. Wprowadzenie rekompensaty $\mathrm{w}$ razie naruszenia przez pracodawcę art. 32 ust. 1 u.z.z, które uzasadnia żądanie jej zapłaty, z jednej strony zabezpiecza interes osoby wykonującej pracę zarobkową niebędącej pracownikiem, a z drugiej rodzi ryzyko niepokrycia otrzymaną rekompensatą strat, jakie taka osoba może ponieść w wyniku niezgodnego z prawem rozwiązania lub wypowiedzenia umowy przez zatrudniającego. Ograniczenie wysokości rekompensaty do sześciokrotności miesięcznego wynagrodzenia mogłoby również budzić wątpliwości w świetle prawa międzynarodowego. Zgodnie ze stanowiskiem organów kontrolnych MOP odszkodowania i kary finansowe w wypadku zwolnienia działacza związkowego powinny być wyższe niż w innych wypadkach bezprawnego rozwiązania stosunku pracy i uwzględniające wielkość przedsiębiorstwa. Komitet Ekspertów ds. Stosowania Konwencji i Zaleceń MOP uznał, że odszkodowanie wynoszące do sześciokrotności miesięcznego wynagrodzenia może być odstraszające w wypadku małych i średnich przedsiębiorstw, ale nie spełnia ono już takiego celu w wypadku

${ }^{6}$ Zdaniem przedstawicieli MOP każdy przypadek dyskryminacji związkowej należy badać indywidualnie. Przykładowo wskazano, że przewodniczący związku zawodowego muzyków, którego zespół otrzymuje co roku zlecenie na zagranie określonego koncertu, ulega dyskryminacji w wypadku, gdy po objęciu przez niego przewodnictwa w związku zawodowym, zespół nagle nie otrzyma zlecenia. Sytuacja taka powinna być zbadana przez sąd (Sprawozdanie z pomocy... 2014, pkt 6-8, 10).

7 W przypadku dochodzenia odszkodowania lub zadośćuczynienia obowiązują regulacje ogólne z Kodeksu cywilnego. Z brzmienia art. 32 ust. 13 u.z.z. wynika, że rekompensata ma charakter zaliczany, tj. musi być zaliczona na poczet odszkodowania lub zadośćuczynienia, a zasądzeniu może podlegać tylko odszkodowanie lub zadośćuczynienie w kwocie przewyższającej (przenoszącej) kwotę rekompensaty. 
przedsiębiorstw dużych (Servais 2017, s. 114). Wątpliwości budzi zaś, że ustawodawca nie wskazał, jak czyni to w art. 3 ust. 3 u.z.z., że do innych niż pracownicy osób stosuje się odpowiednio przepisy ustawy z dnia 17 listopada 1964 roku - Kodeks postępowania cywilnego (Dz.U. 2019, poz. 1460 ze zm., dalej: Kodeks postępowania cywilnego, k.p.c.) o postępowaniu w sprawach z zakresu prawa pracy, a sądem właściwym do rozpoznawania tych spraw jest sąd pracy. Wobec braku określenia właściwości sądu w sprawach o roszczenia z art. 32 u.z.z. osób niebędących pracownikami w literaturze rozważa się dwie opcje interpretacyjne: pierwsza, że są to sprawy z zakresu prawa cywilnego, druga - że są to sprawy z innych stosunków prawnych, do których stosuje się z mocy odrębnych przepisów przepisy prawa pracy (art. $476 \$ 1$ pkt 2 k.p.c.). Trafnie wskazuje się przy tym, że względy funkcjonalne skłaniają do drugiej opcji interpretacyjnej, ponieważ sądy pracy są lepiej przygotowane merytorycznie do rozstrzygania spraw związkowych niż sądy cywilne (Baran 2019, s. 233). Na sąd pracy jako najbardziej właściwy do rozpatrywania spraw, których przedmiotem jest dyskryminacja związkowa osób zatrudnionych na podstawie umów cywilnoprawnych i samozatrudnionych, wskazywała również Misja MOP w Polsce (Sprawozdanie z pomocy... 2014, pkt 6-8, 10).

\section{Sytuacja działaczy związkowych dochodzących roszczeń z tytułu rozwiązania stosunku pracy pomimo braku zgody związku zawodowego}

Nowelizacja z 2018 roku nie przewidziała zmian w zakresie sytuacji przedstawicieli pracowników szczególnie chronionych, z którymi pracodawca, pomimo braku zgody związku zawodowego, rozwiązał stosunek pracy. Warto jednak zauważyć, że propozycja zmian w tym zakresie została zamieszczona w projekcie ustawy o odpowiedzialności podmiotów zbiorowych za czyny zabronione pod groźbą kary, który został przyjęty przez Radę Ministrów dnia 8 stycznia 2019 roku (Ministerstwo Sprawiedliwości 2018). Projekt przewiduje dodanie do Kodeksu postępowania cywilnego art. 7551, w myśl którego w sprawach z zakresu prawa pracy, w których pracownik podlegający szczególnej ochronie przed rozwiązaniem stosunku pracy za wypowiedzeniem lub bez wypowiedzenia dochodzi roszczenia o uznanie wypowiedzenia stosunku pracy za bezskuteczne lub o przywrócenie do pracy, sąd na wniosek uprawnionego może na każdym etapie postępowania udzielić zabezpieczenia przez nakazanie dalszego zatrudniania go przez pracodawcę do czasu prawomocnego zakończenia postępowania. Następnie projektowany przepis stanowi, że w sprawach tych podstawą zabezpieczenia jest jedynie uprawdopodobnienie istnienia roszczenia. Udzielenia zabezpieczenia sąd może odmówić wyłącznie wtedy, gdy roszczenie jest mało prawdopodobne. Sąd uchyla postanowienie o udzieleniu zabezpieczenia, o ile obowiązany wykaże wysokie prawdopodobieństwo bezzasadności roszczenia. W kontekście proponowanych zmian w doktrynie odnaleźć można głosy krytyczne. Podkreśla się, że o ile w celu uzyskania zabezpieczenia w postaci nałożenia na pracodawcę obowiązku dalszego zatrudniania zwolnionego pracownika wystarczyłoby 
jedynie uprawdopodobnienie roszczenia, o tyle dla uchylenia zabezpieczenia pracodawca musiałby wykazać wysokie prawdopodobieństwo jego bezzasadności. Wskazuje się, że $\mathrm{w}$ praktyce wiązałoby się to $\mathrm{z}$ koniecznością przeprowadzenia całego lub prawie całego postępowania dowodowego. Stąd też podnosi się, że takie rozwiązanie przyznawałoby pracownikowi niemal pewność zatrudnienia do czasu prawomocnego zakończenia postępowania sądowego, nawet gdy pracownik dopuścił się ciężkiego naruszenia swoich obowiązków (Pisarczyk 2019, s. 319-320).

Dostrzegając argumenty na rzecz krytycznej oceny projektowanych rozwiązań, warto zastanowić się nad innym rozwiązaniem, które z jednej strony uwzględni ochronę przedstawicieli pracowników, a $\mathrm{z}$ drugiej interes pracodawcy. Jednym ze wskazanych w Zaleceniu nr 143 MOP środków ochrony jest ustanowienie w prawie krajowym specjalnego postępowania odwoławczego dla przedstawicieli pracowników, którzy uważają, że zwolnieni zostali niesłusznie, że warunki ich zatrudnienia zostały zmienione na ich niekorzyść lub że są niesprawiedliwie traktowani (ust. 6 pkt c). Ze stanowiska organów kontrolnych MOP wynika, że postępowanie takie powinno cechować się szybkością (Freedom of Association 2006, $\$ \$ 778,807,820,828$; Servais 2017, s. 114). Komitet Wolności Związkowej wielokrotnie wskazywał, że w wypadkach podejrzenia wystąpienia dyskryminacji antyzwiązkowej właściwe organy zajmujące się sprawami pracy powinny w trybie natychmiastowym podjąć dochodzenie i zastosować odpowiednie środki w celu naprawienia ewentualnych skutków zgłoszonych im przypadków dyskryminacji antyzwiązkowej. Tylko $w$ wypadku niezwłocznego rozstrzygnięcia niezbędne środki zaradcze mogą być rzeczywiście skuteczne. Im dłużej trwa doprowadzenie takiej procedury do końca, tym trudniejsze staje się zapewnienie przez właściwy organ sprawiedliwej, odpowiedniej rekompensaty, ponieważ w sytuacji, której skarga dotyczyła, często mogły już zajść nieodwracalne zmiany (przeniesienia osób itp.) w stopniu, który uniemożliwia nakazanie odpowiedniego zadośćuczynienia lub przywrócenia status quo ante (Freedom of Association 2006, $\$ \$ 821,835$ ). Nadmierna zwłoka w rozpatrywaniu spraw dyskryminacji antyzwiązkowej, w szczególności przedłużająca się zwłoka w zakończeniu postępowań dotyczących przywrócenia do pracy działaczy związkowych zwolnionych przez przedsiębiorstwo, stanowi odmowę dostępu do sprawiedliwości, a więc odmowę praw związkowych dla poszkodowanej osoby (Freedom of Association 2006, $\$ 826$ ). W sprawie, w której postępowanie dotyczące zwolnień trwało już czternaście miesięcy, Komitet Wolności Związkowej - w celu uniknięcia odmowy dostępu do sprawiedliwości - wystąpił do organów sądowych $\mathrm{z}$ wnioskiem o bezzwłoczne wydanie orzeczenia oraz podkreślił, że wszelka dalsza nieuzasadniona zwłoka w postępowaniu sama w sobie może uzasadniać przywrócenie zwolnionych osób na zajmowane poprzednio stanowiska (Freedom of Association 2006, § 827). Tymczasem z danych Ministerstwa Sprawiedliwości wynika, że średni czas trwania postępowania sądowego $\mathrm{w}$ sprawach $\mathrm{z}$ zakresu prawa pracy w Polsce w sądach rejonowych wynosi statystycznie około dziewięciu miesięcy, a w sądach okręgowych około dwunastu miesięcy (Ministerstwo Sprawiedliwości 2017, s. 20-21). Z uwagi na ponadindywidualny wymiar szczególnej ochrony trwałości stosunku pracy, której celem jest stworzenie możliwości reprezentacji praw i interesów pracowników, pożądane 
byłoby zatem ustanowienie w prawie polskim specjalnego trybu rozpoznawania spraw dotyczących ochrony stosunku pracy przedstawicieli pracowników. W szczególności należałoby rozważyć ustanowienie przyspieszonego trybu postępowania w sprawach dotyczących ochrony trwałości stosunku pracy przedstawicieli pracowników.

\section{Wnioski}

Z przedstawionych rozważań wynika, że o ile w świetle prawa międzynarodowego pożądane jest zapewnienie w prawie krajowym środków ochrony działaczom związkowym niebędących pracownikami, o tyle wprowadzone nowelizacją z 2018 roku środki tej ochrony budzą wątpliwości. Ponadto ustawodawca pomimo okazji ku temu, jaką stanowiła nowelizacja, nie dokonał pożądanych zmian w dotychczas obowiązujących unormowaniach z zakresu ochrony przedstawicieli pracowników. $Z$ jednej strony ochrona trwałości zatrudnienia działaczy związkowych jest zbyt daleko idąca, jak w wypadku warunku uzyskania zgody właściwego organu związkowego na rozwiązanie stosunku prawnego czy też nieograniczenia ochrony do przypadków związanych z działalnością związkową. $Z$ drugiej strony obowiązujące przepisy nie zapewniają dostatecznych gwarancji proceduralnych w wypadku naruszenia przez pracodawcę art. 32 u.z.z.

\section{Bibliografia}

Baran K.W. (2018a) O ochronie trwałości stosunku zatrudnienia zwiazkowców na poziomie zakładowym - uwagi de lege ferenda, „Monitor Prawa Pracy”, nr 4.

Baran K.W. (2018b) Refleksje o ochronie stosunku zatrudnienia działaczy zwiazkowych na poziomie zakładowym po nowelizacji ustawy związkowej z 5 lipca 2018 r., „Praca i Zabezpieczenie Społeczne", nr 10.

Baran K.W. (2019) [w:] K.W. Baran (red.), Zbiorowe prawo zatrudnienia. Komentarz, Warszawa. Dral A. (2018) Ochrona trwałości stosunku pracy działaczy związkowych w świetle noweli ustawy o związkach zawodowych, „Studia z Zakresu Prawa Pracy i Polityki Społecznej”, nr 3.

Freedom of Association (2006) Digest of Decisions and Principles of the Freedom of Associations Committee of the Governing Body of the ILO, Geneva.

Gernigon B., Odero A., Guido H. (1998) ILO Principles Concerning the Right to Strike, „International Labour Review”, Vol. 137, No. 4.

Grzebyk P. (2019) [w:] P. Czarnecki, P. Grzebyk, A. Reda-Ciszewska, B. Surdykowska, Ustawa o związkach zawodowych. Komentarz praktyczny z orzecznictwem, Warszawa.

Hodges-Aeberhard J., Odero de Dios A. (1987) Principles of the Committee on Freedom of Association Concerning Strikes, „International Labour Review”, Vol. 126, No. 5.

Kurzynoga M. (2019) Ochrona przedstawicieli pracowników i przysługujące im ułatwienia [w:] K.W. Baran (red.), System prawa pracy, t. 9: Międzynarodowe publiczne prawo pracy. Standardy globalne, Warszawa. 
Ministerstwo Sprawiedliwości (2017) Podstawowa informacja o działalności sq̨dów powszechnych - I pótrocze 2017 r. na tle poprzednich okresów statystycznych, Warszawa.

Ministerstwo Sprawiedliwości (2018) Projekt ustawy o odpowiedzialności podmiotów zbiorowych za czyny zabronione pod groźbą kary i zmianie niektórych ustaw, https://legislacja.rcl.gov. pl/projekt/12312062 (dostęp: 30 stycznia 2020).

Pisarczyk Ł. (2019) Reforma zbiorowego prawa pracy. Próba kodyfikacji a nowelizacja przepisów zbiorowego prawa pracy, Warszawa.

Podgórska-Rakiel E. (2013) Rekomendacje MOP dotyczące wolności koalicji związkowej i ochrony działaczy, „Monitor Prawa Pracy”, nr 2.

Podgórska-Rakiel E. (2014) Konieczność nowelizacji prawa polskiego w kwestii wolności związkowych z perspektywy Międzynarodowej Organizacji Pracy, „Monitor Prawa Pracy”, nr 10.

Servais J.M. (2017) International Labour Law, Wolters Kluwer.

Sobczyk A. (2017) Zakładowy i niezakładowy zwiazek zawodowy a problem demokracji zakładowej [w:] Z. Hajn, M. Kurzynoga (red.) Demokracja w zakładzie pracy. Zagadnienia prawne, Warszawa.

Sprawozdanie z pomocy technicznej MOP w Polsce (2014), http://www.solidarnosc.org.pl/images/ files/zalaczniki/Pomoc_techniczna_MOP.pdf (dostęp: 20 stycznia 2020).

Uzasadnienie rządowego projektu ustawy o zmianie ustawy o związkach zawodowych oraz niektórych innych ustaw (2017) druk sejmowy nr 1933, Sejm VIII kadencji.

\section{Akty prawne}

Konwencja (nr 87) dotycząca wolności związkowej i ochrony praw związkowych, przyjęta w San Francisco dnia 9 lipca 1948 roku, Dz.U. 1958, nr 29, poz. 125.

Ustawa z dnia 23 kwietnia 1964 roku - Kodeks cywilny, Dz.U. 2019, poz. 1145 ze zm.

Ustawa z dnia 17 listopada 1964 roku - Kodeks postępowania cywilnego, Dz.U. 2019, poz. 1460 ze zm.

Konwencja nr 135 dotycząca ochrony przedstawicieli pracowników w przedsiębiorstwach i przyznania im ułatwień, przyjęta w Genewie dnia 23 czerwca 1971 roku, Dz.U. 1977, nr 39, poz. 178.

Zalecenie z 23 czerwca 1971 roku nr 143 Międzynarodowej Organizacji Pracy dotyczące ochrony przedstawicieli pracowników w przedsiębiorstwach i przyznania im ułatwień.

Ustawa z dnia 26 czerwca 1974 roku - Kodeks pracy, Dz.U. 2019, poz. 1040 tekst jedn. ze zm.

Ustawa z dnia 23 maja 1991 roku o związkach zawodowych, Dz.U. 2019, poz. 263 tekst jedn.

Ustawa z dnia 4 marca 1994 roku o zakładowym funduszu świadczeń socjalnych, Dz.U. 2019, poz. 1352 tekst jedn. ze zm.

Ustawa z dnia 5 lipca 2018 roku o zmianie ustawy o związkach zawodowych oraz niektórych innych ustaw, Dz.U. 2018, poz. 1608 ze zm. 